\title{
Anatomy of the Facial Nerve and its Implication in the Surgical Procedures
}

\author{
Anatomía del Nervio Facial y sus Implicancias en los Procedimientos Quirúrgicos \\ "Antonio de Castro Rodrigues; * Jesus Carlos Andreo; *"Laura de Freitas Menezes; \\ *** Tatiana Pimentel Chinellato \& *Geraldo Marco Rosa Júnior
}

RODRIGUES, D. C. A.; ANDREO, J. C.; MENEZES, D. F. L.; CHINELLATO, P. T. \& ROSA-JÚNIOR, G. M. Anatomy of the facial nerve and its implication in the surgical procedures. Int. J. Morphol., 27(1):183-186, 2009.

SUMMARY: Facial palsy, parotid diseases and others are a relatively common clinical condition with a variety of causes. Irrespective of its etiology, facial palsy always represents a very serious problem for the patient. Parotid gland diseases also are very common occurrence. In this particular case, the knowledge of surgical anatomy of the facial nerve and its correlations with the parotid gland is very important for an adequate preservation in the cases of surgery of benign and malignant diseases of the parotid gland. Although the surgical anatomy of the facial nerve has been well documented, the concept of surgical treatment for parotid tumors, facial palsy (neurorraphy techniques) and submandibular surgical approach are rarely challenged now.

KEY WORDS: Facial nerve; Surgical anatomy; Facial palsy; Parotid gland.

\section{INTRODUCTION}

The facial nerve consists of the facial nerve proper and the intermedius nerve. The former originates from motoneurons in the facial nucleus situated ventrolaterally in the caudal portion of the pons. The motor axons first turn dorso-medially towards the abducens nucleus round the dorsal side of this nucleus and then course ventrolaterally. Both the facial nerve proper and the intermedius nerve emerge from the CNS in the cerebellopontine angle at the caudal border of the pons, between the abducens nerve and the statoacoustic nerve (Machado, 1998).

As it exits through the stylomastoid foramen, the extracranial portion of the facial nerve may be located $5 \mathrm{~cm}$ below the skin. Here, it immediately gives off branches to the auricular muscles, the posterior belly of the digastric muscle and the stylohyoid muscle. It supplies sensory (vagal) fibers to parts of the external auditory canal and some areas to the auricle, including the lobulus (Ranson \& Clark, 1959; Barr \& Kiernan, 1983; May \& Schaitkin, 2000). The nerve then courses ventrally and at the posterior edge of the parotid gland, it splits into upper and lower divisions. Within the parotid gland, there is further branching with many individual variations (Davis et al., 1956). As a rule, the upper division of the facial nerve gives off temporal, zygomatic and buccal branches, whereas the lower division emits marginal mandibular and cervical branches.

There are 23 facial muscles, most of which are paired. In facial expressions, 17 muscles are activated (Freilinger $e t$ al., 1990).

The knowledge of surgical anatomy of the facial nerve and its correlations with the parotid gland and facial muscles are very important for an adequate preservation in the cases of surgery in this area. The iatrogenic injury in this facial region is very common. The choice of the surgical approach is very relevant in the parotid surgery because of the extreme anatomic variability of the parotideal area and the functional importance of the branches of facial nerve.

\section{MATERIAL AND METHOD}

Fifteen cadavers were dissected. They came from Laboratory of Anatomy (University of São Paulo - FOB/

\footnotetext{
* Department of Biological Sciences, FOB / USP, Bauru, São Paulo, Brazil.

** Laboratory of Anatomy Intern FOB/USP/Bauru, São Paulo, Brazil.

${ }^{* * *}$ University of Sacrated Heart, Student USC/Bauru, São Paulo, Brazil.
} 
USP/Bauru). All of them were fixed in 10\% formalin solution before dissection procedures. Ages ranged from 35 to 74 years, of which 12 were males and 3 females.

Dissection of the facial nerve of these cadavers was performed after opening the skin during the classes of the dentistry graduation course.

To dissect the facial nerve, facial muscles and parotid gland a surgical microscope (DF-Vasconcelos) was used in order to avoid sectioning delicate branches.

To obtain a descriptive explanation about the facial nerve and its branches proposed in this study, special dissecting instruments and digital photographic machine were utilized. Special attention was taken for observation of the branches going to the mimic muscles.

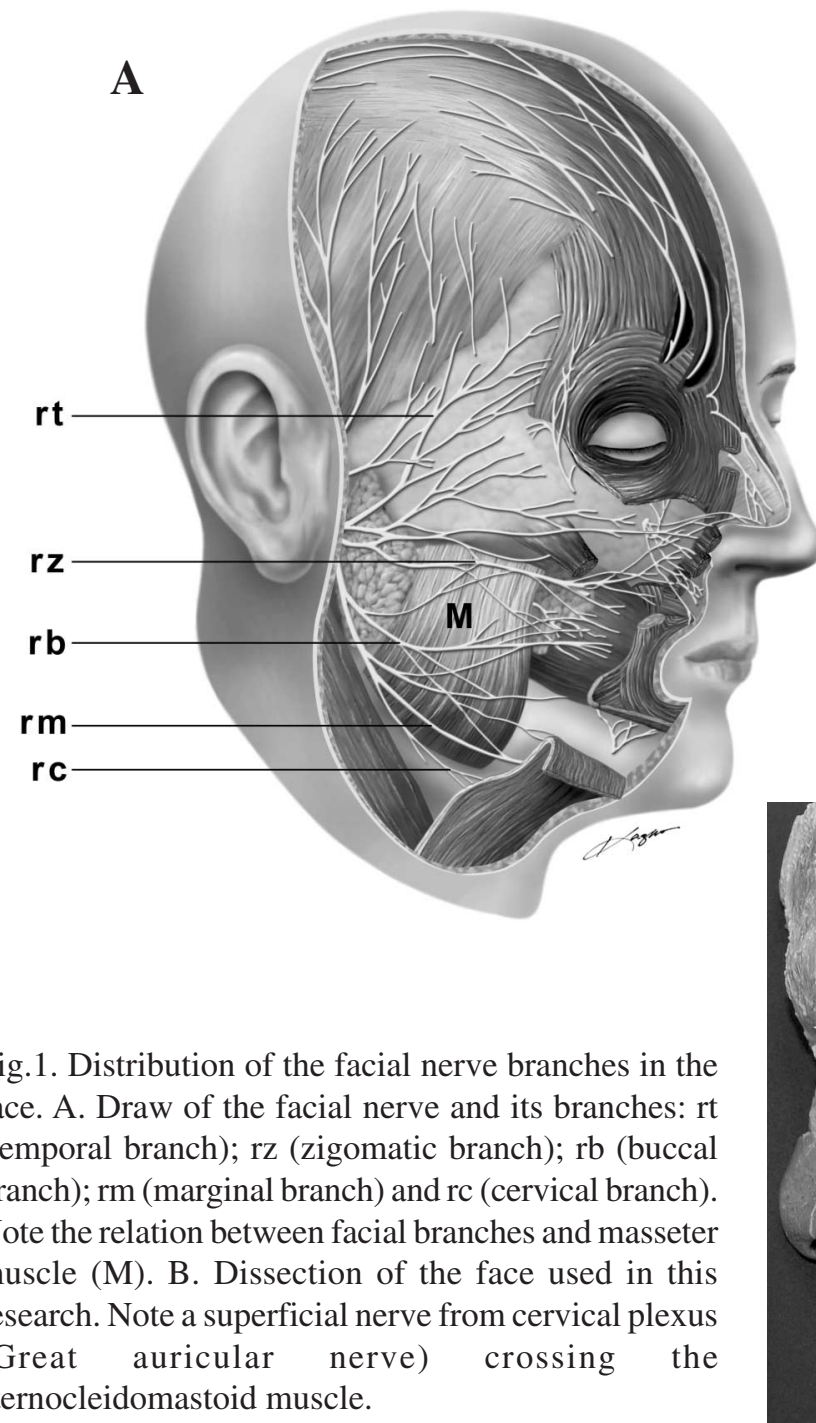

\section{RESULTS}

After emerging from stylomastoid foramen, the facial nerve gives off branches to the auricular muscles, the posterior belly of the digastricus muscle and the stylohyoid muscle before it penetrates in the posterior edge of the parotid gland. Inside parotid gland the facial nerve normally constitutes a small trunk about one $\mathrm{cm}$ longer. After that, it splits into upper and lower divisions. Within the parotid gland, there is further branching with many individual variations. It was found that the upper division of the facial nerve gives off temporal, zygomatic and buccal branches, whereas the lower division emits marginal mandibular and cervical branches (Fig.1). The latter innervate the platysma and may communicate with the cervical plexus and/or tertiary branches of the facial nerve are interconnected. Subsequently, the facial nerve branches leave de parotid gland and enter the face, where they continue further distally covered by the skin, subcutaneous tissue and facial muscles.

Posterior to the facial artery the marginal mandibular branch run above the inferior margin of the mandible and divided into two branches at the point of emergence from the parotid gland. The facial nerve branches normally penetrate de facial muscles for the deep surface. Some variations in this particular distribution could be found in some cadavers. For instance, zygomatic nerve branch passing over the zygomatic muscle was observed in two cadavers. As regard to the marginal mandibular branch, we could find that in the majority ran above the inferior border of the mandible. In some cases, below the inferior border of the mandible it was divided into two branches at the crossing point with the facial artery.

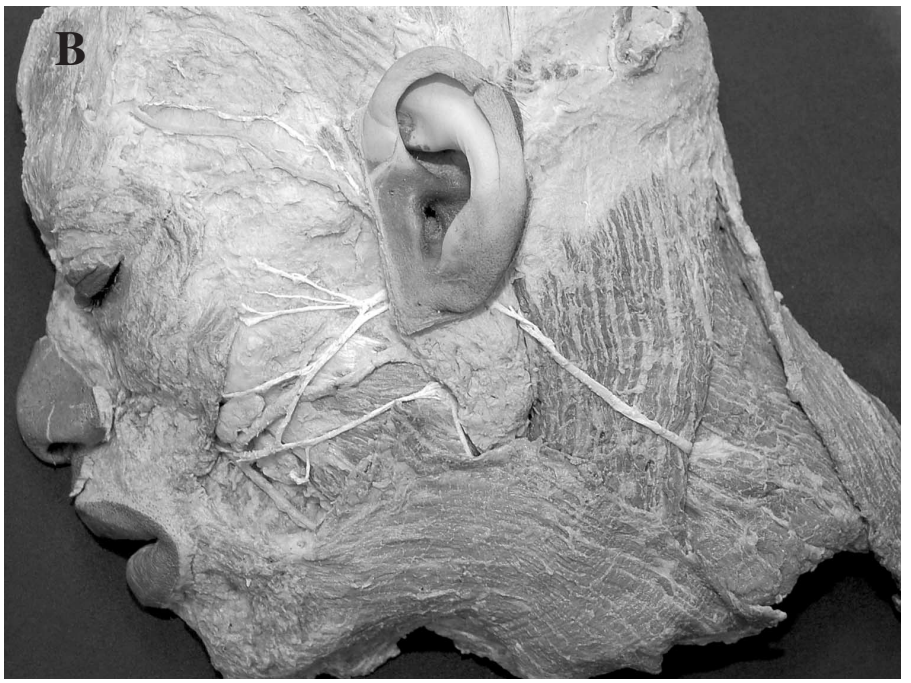




\section{DISCUSSION}

The surgical treatment for tumors, especially in the parotid gland, is rarely challenged at the present time, although the surgical anatomy of the facial nerve has been well documented. Heeneman (1975) and de Ru (2001), claims that the principle with functional and anatomical preservations of all branches of the facial nerve whenever possible, the amount of normal tissue to be removed in continuity with the tumor is very difficult to manage during the surgery. For this reason we decided to do a short outline of anatomical relations between the facial nerve and its branches and other anatomical structures in the face in order to avoiding, isolating and protecting the referred nerve during surgical procedures

Several descriptions about the parotid gland and its relation with the facial nerve can be found in the literature (Dingman \& Grabb, 1962; Guerrero-Santos, 1978; Baker \& Conley, 1979). By the other hand, the correlation between the anatomy of facial nerve and surgical procedures deserve more detailed descriptions. Some authors describe surface landmarks to identify the facial nerve branches (Furnas, 1965; Dingman \& Grabb; Bernstein \& Nelson, 1984; Niccoli-Filho \& Varandas, 1988). It is important to notice that, because of the anterolateral course of the facial nerve, the peripheral branches are located more superficially.

In $28 \%$ of cases the facial nerve gives off five branches: temporal, zigomatic, bucal, marginal and cervical branches.

In relation to the temporal and zigomatic branchs, our results are similar to the Furnas. It is running between the lower part of the ear lobe and the lateral edge of the eyebrow. It is possible to reach this branch within an area bounded by a line from the earlobe to the lateral edge of the eyebrow inferior and a second line from the tragus to the lateral coronal suture just above and behind the highest forehead crease. In this area nerve injury near to the temporal vessels is more likely, since we could find great variability to the course of these vessels in relation to the temporal branches of the facial nerve.

The buccal branches of the facial nerve in relation to the parotid duct associated with surgical procedures such as rhytidectomy and parotid gland surgery are relevant. It was find a vertical and horizontal relationship between the buccal branches, tragus, and parotid duct. This relationship was variable in the studied specimens. We could find simple branch beneath and above the parotid duct. In one case buccal and other branches formed a plexus. Finally, it was possible observing two branches of buccal branch: one superior and one inferior to the duct at the point of emergence from the parotid gland. These results are similar to the others authors (Saylam et al., 2007).

The marginal branch deserves a very careful description. Normally this branch is described in relationship to the lower border of the mandible. In our dissections we could find that one or more rami of marginal branch formed a downward arc whose lowest point extended up $1.0 \mathrm{~cm}$ below the inferior border of the mandible. This result is similar to the other authors that have found the same disposition in 19\% of the studied specimens (Niccoli-Filho \& Varandas). For this reason, an incision $3 \mathrm{~cm}$ beneath the inferior border of the mandible is recommended when it is necessary to reach the submandibular region.

Finally, the cervical branch normally is smaller if compared to the other branches. It emerges from inferior border of parotid gland and runs to the cervical region. It innervates the inferior portion of the platisma muscle while the superior portion is innervated for marginal branches. This result is different of Zani (1997). For this author the platisma muscle is totally innervated for cervical branches. Lesions in the cervical branch are not so important under functional point of view if compared to the other facial nerve branches.

In brief, the facial nerve can be injured in different regions besides cited above: a) it can be injured in the intracranial portion. In this case traumatic lesions such as skull base fractures are observed; b) it can be injured in the extracranial portion. In this case the facial nerve can be affected by a Schwannoma at its exit through the stylomastoideum foramen.

Furthermore, some other conditions, such as the Guillain-Barré syndrome, infectious mononucleosis, cytomegalovirus infection, sarcoidosis, acute porphyries, amyloidosis and botulism may cause facial damage. Conduction block, or first-degree injury (Sunderland, 1978), is the mildest nerve lesion.

\section{ACKNOWLEDGEMENTS}

The authors thank Miss Vivian Cristina Rosa for the technical support. 
RODRIGUES, D. C. A.; ANDREO, J. C.; MENEZES, D. F. L.; CHINELLATO, P. T. \& ROSA-JÚNIOR, G. M. Anatomía del nervio facial y sus implicancias en los procedimientos quirúrgicos. Int. J. Morphol., 27(1):183-186, 2009.

RESUMEN: La parálisis facial, enfermedades de la parótida y otras patologías son una condición clínica relativamente común con una variedad de causas. Independientemente de su etiología, la parálisis facial siempre representa un problema muy serio para el paciente. Las enfermedades de la glándula parótida son también de una ocurrencia común. En este caso particular, el conocimiento de la anatomía quirúrgica del nervio facial y su correlación con la glándula parótida es de mucha importancia para una adecuada preservación de la misma, en casos de cirugía como tratamiento de enfermedades benignas o malignas. Aunque la anatomía quirúrgica del nervio facial es bien documentada, el concepto de tratamiento quirúrgico para los tumores parotídeos, parálisis facial (técnicas de neurorrafia) y acercamiento quirúrgico submandibular son raramente impugnados hoy en día.

PALABRAS CLAVE: Nervio facial; Anatomía quirúrgica; Parálisis facial; Glándula parótida.

\section{REFERENCES}

Baker, D. C. \& Conley, J. Avoiding facial nerve injuries in rhytidectomy. Anatomical variations and pitfalls. Plast. Reconstr. Surg., 64(6):781-95, 1979.

Barr, M \& Kiernan, J. The human nervous system: an anatomical viewpoint. $4^{\text {th }}$ ed. Philadelphia, Harper \& Row, 1983.

Bernstein, L. \& Nelson, R. H. Surgical anatomy of the extraparotid distribution of the facial nerve. Arch. Otolaryngol., 110(3):177-83, 1984.

Davis, R. A.; Anson, B. J.; Budinger, J. M. \& Kurth, L. R. Surgical anatomy of the facial nerve and parotid gland based upon a study of 350 cervical facial halves. Surg. Gynecol. Obstet., 102(4):385-412, 1956.

de Ru, J. A.; van Benthem, P. P.; Bleys, R. L.; Lubsen, H. \& Hordijk, G. J. Landmarks for parotid gland surgery. J. Laryngol. Otol., 115:122-5, 2001.

Dingman, R. O. \& Grabb, W. C. Surgical anatomy of the mandibular ramus of the facial nerve based on the dissection of 100 facial halves. Plast. Reconstr. Surg.Transplant Bull., 29:266-72, 1962.

Freilinger, G.; Happak, W.; Burggasser, G. \& Gruber, H. Histochemical mapping and fiber size analysis of mimic muscles. Plast. Reconstr. Surg., 86(3):422-8, 1990.

Furnas, D. W. Landmarks for the trunk and temporal division of the facial nerve. Br. J. Surg., 52:694-8, 1965.

Guerrero-Santos, J. The role of the platysma muscle in rhytidoplasty. Clin. Plast. Surg., 5(1):29-49, 1978.

Heeneman, H. Identification of the facial nerve in parotid surgery. Can. J. Otolaryngol., 4(1):145-51, 1975.

Machado, A. Neuroanatomia functional. $2^{\text {nd }}$ ed. São Paulo. Ed. Atheneu, 1998.

May, M. \& Schaitkin, B. The facial nerve. $2^{\text {nd }}$ ed. New York, Thieme, 2000.

Niccoli-Filho, W. \& Varandas, J. T. Surgical anatomy of the facial nerve and the parotid gland. Rev. Odontol. USP, $21: 48-50,1988$.

Ranson, S. \& Clark, S. The anatomy of the nervous systemIts development and function. $10^{\text {th }} \mathrm{ed}$. Philadelphia, W. B. Saunders Comp, 1959.

Saylam, C.; Ucerler, H.; Orhan, M.; Uckan, A. \& Ozek, C. Localization of the marginal mandibular branch of the facial nerve. J. Craniofac. Surg., 18(1):137-42, 2007.

Sunderland, S. Nerves and nerve injuries. $2^{\text {nd }}$ ed. London, Churchill Livingstone, 1978.

Zani, R. Ritidoplastias e Nervo Facial: Como Evitar as Lesões dos seus Ramos. Rio de Janeiro, Ed. Revinter, 1997.

Correspondence to:

Antonio de Castro Rodrigues, PhD

Department of Biological Science - Anatomy

Av. Otávio Pinheiro Brisola 9-75 - Aeroporto

17012-901

Bauru/São Paulo

BRASIL

Email: acastro@fob.usp.br

Received: 26-05-2008

Accepted: 22-12-2008 